\title{
Scholarship Decision Support System Using Preference Ranking Organization Method for Enrichment Evaluation
}

\author{
Qurrotul Aini, Nur Aeni Hidayah, \& Annisa Nurul Istiqomah \\ Department of Information System, Syarif Hidayatullah State Islamic University \\ Tangerang Selatan 15412 Indonesia \\ qurrotul.aini@uinjkt.ac.id
}

\begin{abstract}
Dompet Dhuafa Republika is a nonprofit institute that uplift the dignity of a poor social humanity with ZISWAF funds and other funds lawful and legal, from individuals, groups and companies. The decision making process in the selection of the SMART EI scholarship awardee is still to estimate by Manager and central selection committee based on the poverty of eligible nominee only and must wait for the report from the selection committee in the area for several months. If there is a change in the education system of local education system, it can affect the selection and ranking system. This leads to lack of effective process of determining scholarship awardee. The purpose of this research is in order to design a decision support system that can simplify the process of determining scholarship awardee. To develop Decision Support Systems (DSS) of Scholarship, it apply Rapid Application Development (RAD) using Unified Modeling Language (UML), programming language PHP, XAMPP as a web server and MySQL as database. Refer to interview result with Research Manager, the system is capable of handling and make ease to determine scholarship awardee using PROMETHEE stage II.
\end{abstract}

Keywords-decision support system; promethee; RAD; scholarship; awardee.

\section{INTRODUCTION}

Dompet Dhuafa Republika is a nonprofit institute that uplifts the dignity of poor social humanity with ZISWAF funds and other funds lawful and legal, from individuals, groups and companies. One of the scholarship programs in Dompet Dhuafa Republika is SMART EI. Manager SMART EI and central selection committee have to estimatie the scholarship awardee by only poverty of nominees and must wait for the report from local selection committee in few months. Moreover, if there is a change in the local education system, it can affect selection of awardee. In term of the input-process-output logic [1-5], the logic can be used for simplifying the selection process. The objective of this research is simplify the process of determining scholarship awardee with build decision support system.

Some previous research has been done before dealing with Promethee. In addition to its implementation within the organization, DSS is also applied in the fields of education, construction, finance, and company such as employee allocation in accordance with company performance and standards [6]. Refer to [7], they presented DSS to support decision making in portfolio investment with Promethee method. In [8], the process of supporting the manager's performance in determining employee bonuses with Promethee method was

explained in details. Meanwhile, in education field, DSS is also designed to determine the Supersemar Scholarship awardee using Promethee [9]. Promethee is used to select suitable machine tool in manufacturing companies [10]. Also, a hybrid between AHP and Promethee can be used to select the equiment [11]. Therefore, authors proposed the DSS of scholarship awardee using Promethee method. The contributions of this research are:

- Specify the criterion to decide scholarship awardee

- Propose the Promethee scholarship awardee model

- Build decision support system for selection of scholarship awardee.

\section{LITERATURE REVIEW}

A system intended to support managerial decision makers in semi-structured decision situations. Decision support system is a tool for decision makers to expand their capabilities, but not to replace their judgment. DSS is intended for decisions that require judgment or decisions that are not at all supported by algorithm [12].

Multiple Criteria Decision Making (MCDM) is a decision-making method to establish the best alternative of a number of alternatives based on certain criterion. Based on its objectives, MCDM can be divided into two models, Multiple Attribute Decision Making (MADM) and Multi Objective Decision Making (MODM) [13]. Promethee is included in MADM methods. Promethee is a method of determining the order (priority) in a multicriteria analysis. In this method, important information is given from differences by evaluating a criterion and that must be considered in analyzing that is the largest difference, a strong intensity in the choice for a criterion above the other. The alleged predominance of criterion used in Promethee is the use of value in outranking relationships [14].

The aim of Promethee is to be easily for decision maker to solve a problem. In this method, important information is given from differences by evaluating a criterion and must be considered in analyzing that is the largest difference, a strong intensity in the choice for a criterion among the others [15]. Promethee provides user to use data directly in simple multicriteria tables. Promethee has the ability to handle multiple comparisons, the decision maker simply defines its own size scale without constraint, to indicate its 
priority and preference for each criterion by focusing on values, without thinking about calculation method.

\section{A. Identify Alternatives and Criterion}

The value of $\mathrm{f}$ is real value from a criterion: [15]

$$
f: \mathrm{K} \rightarrow \mathrm{R}
$$

For each alternative $a \in \mathrm{K}, f(a)$ is an evaluation and an alternative to a criterion. An alternative a is evaluated in some criterion $\mathrm{k}$ which must maximize or minimize it. Intensity delivery $(P)$ of alternative preferences $a$ to alternative $b$ :

- $P(a, b)=0$, it means there is no different between $a$ and $b$ or there is no preference from $a$ better than $b$.

- $P(a, b) \sim 0$, it means weak, preference from $a$ is better than $b$.

- $P(a, b) \sim 1$, it means strong, preference $a$ is better than $b$.

- $P(a, b)=1$, it means absolute, preference $a$ is better than $b$.

\section{B. Recommendation Preference Funciton for Application \\ Purposes}

In Promethee, there are six types of criterion functions presented. These are of course not absolute, but its good enough for some cases.

TABLE I.

CRITERION PREFERENCE

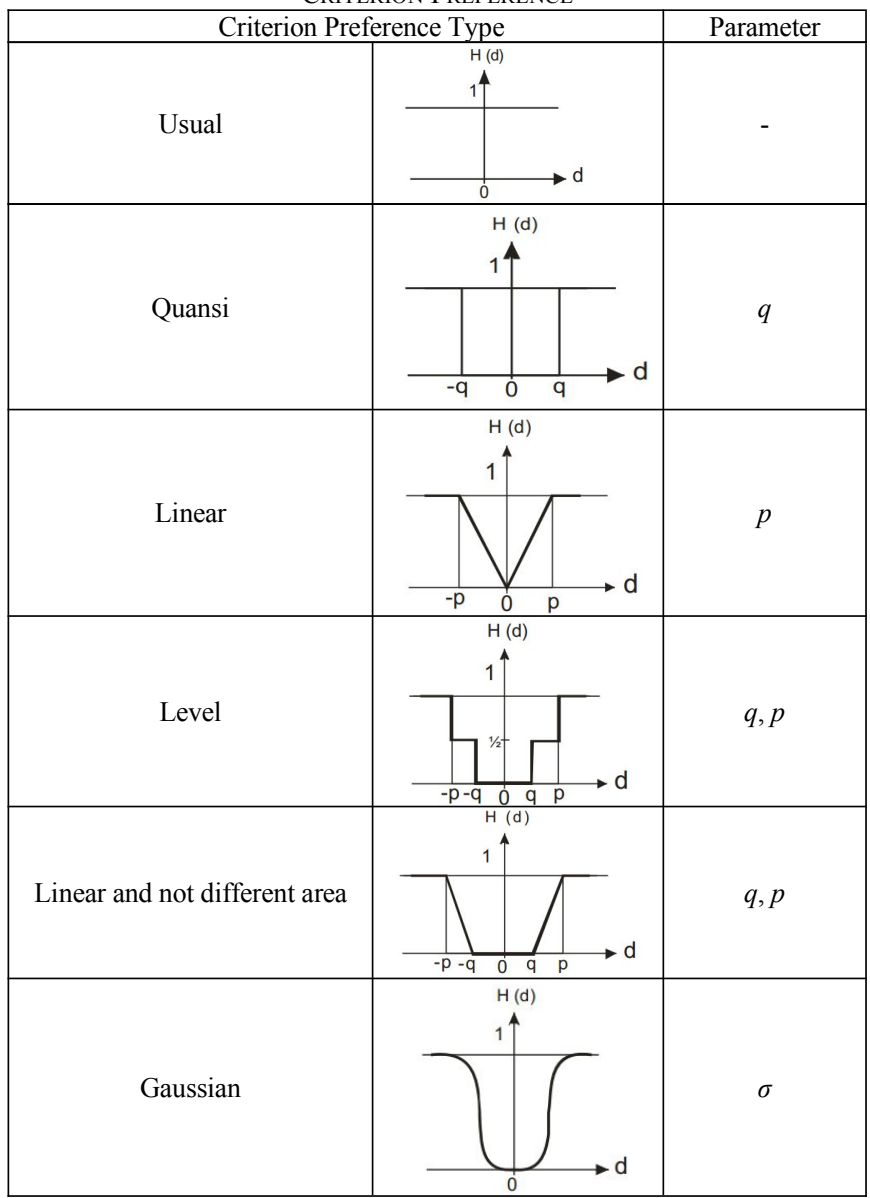

\section{Multicriteria Preference Index}

The multicriteria preference index is calculated for each pair of criterion by the following equation.

$$
\sigma(a, b)=\sum_{i=1}^{n} \pi P_{i}(a, b) ; \forall a, b \in A
$$

\section{Promethee Ranking}

The direction of preference is considered based on an index value:

Leaving flow (LF): $\Phi^{+}(a)=\frac{1}{n-1} \sum_{x \in A} \delta(a, x)$

Entering flow (EF): $\Phi^{-}(a)=\frac{1}{n-1} \sum_{x \in A} \delta(a, x)$

Net flow (NF): $\Phi(a)=\Phi^{+}(a)-\Phi^{-}(a)$

\section{RESEARCH METHOD}

To conduct this research, we apply Rapid Application Development (RAD) approach. There are three steps to develop DSS according to RAD, i.e. Requirements planning, workshop design, and implementation. In Fig. 1, it illustrates DSS development. Each step is include some activities, that must completed before conduct next step. For instance, requirements planing, we must identify the problem in company, gather the information that we need, and solve the problem regarding the previous related work with literature survey and observation. Some tools are required to build DSS, i.e. Unified Modeling Language (UML), programming language PHP, XAMPP as a web server and MySQL as database [16-20].

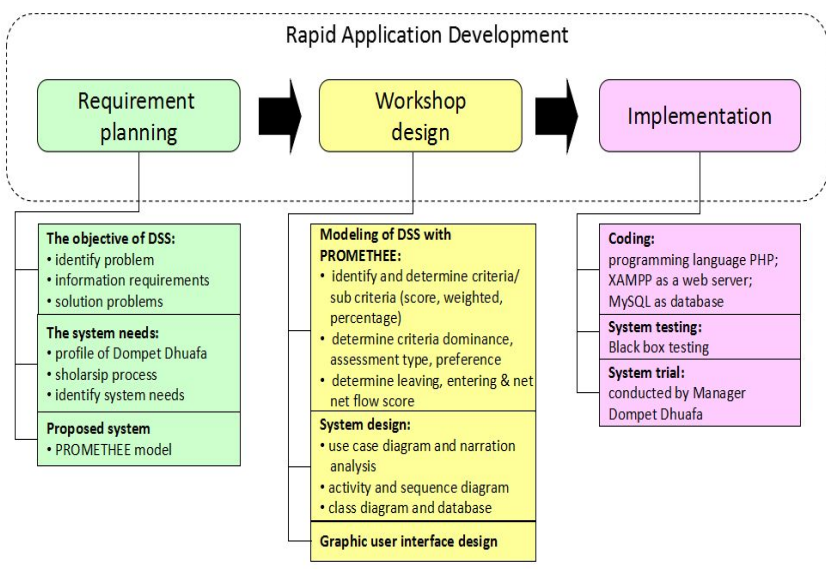

Fig. 1. Development of scholarship DSS

\section{Modeling DSS with PrometheE}

Refer to process that described in Fig. 2, scholarship DSS model with Promethee is described as follow:

\section{A. Identify and Determine Criterion}

From significant information each nominee, the criterion of scholarship awardee consist of four parameters, i.e. academic report, house index, a number of dependent member's family, and parent's salary (Fig. 2). Assessment of these criteria also varies by using a 90-50 scale. For more 
details about the description of promethee assessment, it can be seen in Table I.

\section{B. Determine Criterion Dominance, Assessment \& Preference}

The next step, it illustrates in Table 2, determine the weight of each alternative along with the criterion, the predominance of the criterion, the type of assessment (Max/ Min), and the type of preference for each criterion. The following is a process of calculating the weighted criterion applied to an existing alternative:

1) Preference score $P\left(a_{1}, a_{2}\right)$ pairs between $a_{1}=$ nominee $_{1}$ and $a_{2}=$ nominee $_{2}$, the result as follows:

- For $f_{1}=$ academic report, using Preference I formula: where $d=$ the difference of criterion score

$\left\{d=f\left(a_{1}\right)-f\left(a_{2}\right)\right\}$

$d=16.4-16.8=-0.4$

According to minimize rule, it obtained

$H(d)=\left\{\begin{array}{l}0, \text { if } d=0 \\ 1, \text { if } d \neq 0\end{array}\right.$

then $P\left(a_{1}, a_{2}\right)=1$ and $P\left(a_{2}, a_{1}\right)=1$

- $\quad$ For $f_{2}=$ house index, using Preference III formula: where $d=$ the difference of criterion score, $p=$ level criterion

$$
\begin{aligned}
& \left\{d=f\left(a_{1}\right)-f\left(a_{2}\right)\right\} \\
& d=19.63-20=-0.37 ; p=10
\end{aligned}
$$

According to minimize rule, it obtained

$$
H(d)=\left\{\begin{array}{l}
d / p, \text { if }-p \leq d \leq p \\
1, \text { if } d<-p \text { or } d>p
\end{array}\right.
$$

then $P\left(a_{1}, a_{2}\right)=-0.037$ and $P\left(a_{2}, a_{1}\right)=0.037$

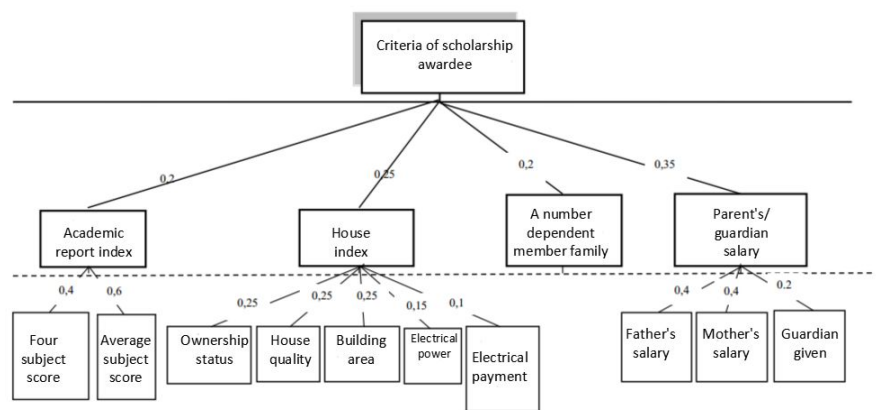

\begin{tabular}{|c|c|}
\hline \multicolumn{2}{|c|}{ PROMETHEE ASSESSMENT } \\
\hline Score & Description \\
\hline 90 & very worthy \\
\hline 80 & worthy \\
\hline 70 & quite worthy \\
\hline 60 & less worthy \\
\hline 50 & not worthy \\
\hline
\end{tabular}

Fig. 2. Criterion of scholarship awardee

TABLE II.

- For $f_{3}=$ a number dependent member family, using Preference II formula: where $d=$ the difference of criterion score, $q=$ quansi criterion

$$
\begin{aligned}
\{d & \left.=f\left(a_{1}\right)-f\left(a_{2}\right)\right\} \\
d & =3.2-2.40=0.8 ; q=10
\end{aligned}
$$

\begin{tabular}{|c|c|c|c|c|c|c|}
\hline \multirow{2}{*}{$\begin{array}{l}\text { Criterion } \\
\quad(f)\end{array}$} & \multirow{2}{*}{$\begin{array}{l}\operatorname{Min} / \\
\max \end{array}$} & \multicolumn{3}{|c|}{$\begin{array}{c}\text { Scholarship alternative } \\
\text { score }\end{array}$} & \multirow{2}{*}{$\begin{array}{l}\text { Preference } \\
\text { Type }\end{array}$} & \multirow[t]{2}{*}{ Parameter } \\
\hline & & $a_{1}$ & $a_{2}$ & $a_{3}$ & & \\
\hline $\begin{array}{l}\text { Academic } \\
\text { report }\end{array}$ & $\max$ & 16.4 & 16.8 & 17.2 & I & - \\
\hline $\begin{array}{l}\text { House } \\
\text { index }\end{array}$ & $\min$ & 19.6 & 20.0 & 16.25 & III & $p=10$ \\
\hline $\begin{array}{c}\text { A number } \\
\text { dependen } \\
\text { t member } \\
\text { family }\end{array}$ & $\max$ & 3.2 & 2.4 & 3.2 & II & $q=10$ \\
\hline $\begin{array}{l}\text { Parents/ } \\
\text { guardian } \\
\text { salary }\end{array}$ & $\min$ & 51.8 & 51.8 & 46.9 & IV & $p=50, q$ \\
\hline
\end{tabular}

According to maximize rule, it obtained

$$
\begin{aligned}
& H(d)=\left\{\begin{array}{l}
0, \text { if }-q \leq d \leq q \\
1, \text { if } d<-q \text { atau } d>q
\end{array}\right. \\
& \text { then } P\left(a_{1}, a_{2}\right)=0 \text { and } P\left(a_{2}, a_{1}\right)=0
\end{aligned}
$$

TABLE III.

Preference, Min/MaX And Alternative

- For $f_{4}=$ parents/guidance salary, using Preference IV formula:

where $d=$ the difference of criterion score, linear preference for $p$ and $q$

$$
\begin{aligned}
& \left\{d=f\left(a_{1}\right)-f\left(a_{2}\right)\right\} \\
& d=51.8-51.8=0 ; p=50 \text { and } q=10
\end{aligned}
$$

According to maximize rule, it obtained

$$
H(d)=\left\{\begin{array}{l}
0, \text { if }|d| \leq q \\
0.5, \text { if } q<|d| \leq p \\
1, \text { if } p<|d|
\end{array}\right.
$$

then $P\left(a_{1}, a_{2}\right)=0$ and $P\left(a_{2}, a_{1}\right)=0$

$$
\begin{aligned}
& \sigma(a, b)=\sum_{i=1}^{n} \pi P_{i}(a, b) ; \forall a, b \in A \\
& \delta\left(a_{1}, a_{2}\right)=1 / 4(1+(-0.37)+0+0)=0.24 \\
& \delta\left(a_{2}, a_{1}\right)=1 / 4(1+0.37+0+0)=0.26
\end{aligned}
$$

2) For $P\left(a_{1}, a_{3}\right)$, the results become:

$$
\begin{aligned}
& \sigma(a, b)=\sum_{i=1}^{n} \pi P_{i}(a, b) ; \forall a, b \in A \\
& \delta\left(a_{1}, a_{3}\right)=1 / 4(1+0.8+0+0)=0.333 \\
& \delta\left(a_{3}, a_{1}\right)=1 / 4(1+(-0.8)+0+0)=0.17
\end{aligned}
$$

3) For $P\left(a_{2}, a_{3}\right)$, the results become:

$$
\begin{aligned}
& \sigma(a, b)=\sum_{i=1}^{n} \pi P_{i}(a, b) ; \forall a, b \in A \\
& \delta\left(a_{2}, a_{3}\right)=1 / 4(1+0.375+0+0)=0.344 \\
& \delta\left(a_{3}, a_{2}\right)=1 / 4(1+(-0.375)+0+0)=0.156
\end{aligned}
$$




\section{Determine leaving flow, entering flow and net flow score}

After it obtained all the preference index score, then with promethee 1 can get leaving flow and entering flow index to determine the relative preference of an alternative to other nominee.

TABLE IV.

Alternatives Flow Data of Scholarship Awardee

\begin{tabular}{|c|c|c|c|}
\hline Nominee $\left(a_{\mathrm{n}}\right)$ & $a_{1}$ & $a_{2}$ & $a_{3}$ \\
\hline$a_{1}$ & - & 0.24 & 0.333 \\
\hline$a_{2}$ & 0.26 & - & 0.344 \\
\hline$a_{3}$ & 0.17 & 0.156 & - \\
\hline
\end{tabular}

Table IV shows the leaving flow (LF), entering flow (EF) and net flow (NF) score and ranking level of alternatives.

TABLE $\mathrm{V}$.

LF, EF, NF SCORE, AND RANKING

\begin{tabular}{|c|c|c|c|c|}
\hline Nominee $\left(a_{\mathrm{n}}\right)$ & LF & EF & NF & Rank \\
\hline$a_{1}$ & 0.191 & 0.143 & 0.048 & 1 \\
\hline$a_{2}$ & 0.201 & 0.132 & 0.069 & 2 \\
\hline$a_{3}$ & 0.108 & 0.226 & -0.118 & 3 \\
\hline
\end{tabular}

\section{SYTEM DEVELOPMENT}

To build system design, we use object oriented model. First, we create use case diagram and its narration. In use case diagram, some activities has been done, for example: identify the system actor and use case. Fig. 3 depicts the use case diagram of scholarship DSS. In this use case, there are two actors, i.e. Administrator and Manager of SMART EI. The manager get the report from PROMETHEE calculation and determine the scholarship awardee. We create the activity, sequence, and class diagram. Finally, we design GUI as interface between system and user (Fig. 4). To complete the system development, it must reach in implementation stage. In this stage, This stage consists of two, i.e. the implementation of a system design into programming language (coding) and system testing by some owners, analyst, and developer with the purpose that a system can run well at the time of operation or there are still errors. At last, the evaluation by manager dealing with this system. Encoding is done by using PHP programming language, and MySQL as its data base as well as web-based and in accordance with it designs.

\section{CONCLUSION}

The criterion for scholarship awardee is determined by scholarship management team (interviews and observations and a regulation of Ministry of National Education. Applying Promethee method, the order (priority) of the multicriteria analysis can be determined. Developing decision support system based on web can accelerate the process of determining the scholarship awardee, therefore, it saves time in the selection stage. In the future work, to gain knowledge of approaches and results, it is necessary to determine scholarship awardee using other methods, such as TOPSIS, ELECTRE or metaheuristic approaches. In order to input data into a system, to be more valid and accurate, additional sensitivity test is required.

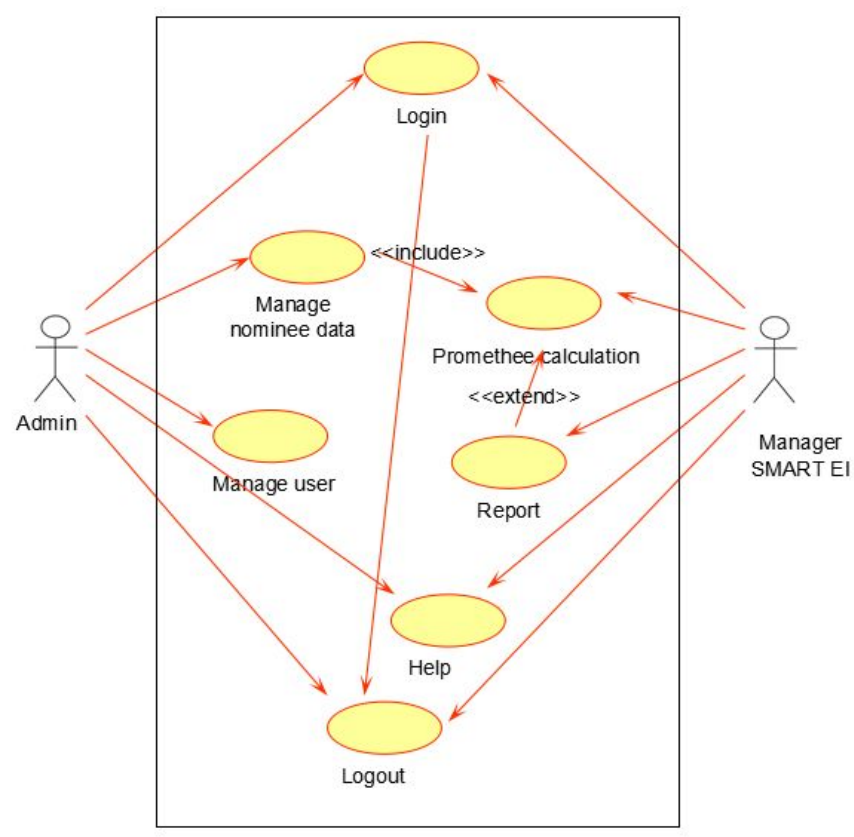

Fig. 3. Use case diagram of scholarship DSS

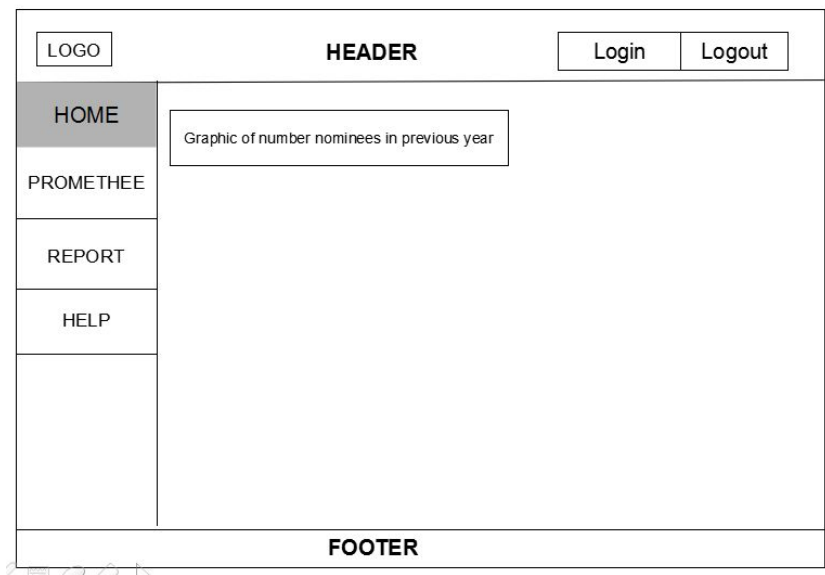

Fig. 4. GUI Front end of scholarship DSS

\section{REFERENCES}

[1] A. Subiyakto, A. R. Ahlan, M. Kartiwi, and S. J. Putra, "Measurement of the information system project success of the higher education institutions in Indonesia: a pilot study," International Journal of Business Information System, vol. 23, pp. 229-247, 2016.

[2] A. Subiyakto, A. R. Ahlan, M. Kartiwi, S. J. Putra, and Y. Durachman, "The User Satisfaction Perspectives of the Information System Projects," Indonesian Journal of Electrical Engineering and Computer Science, vol. 4, 2016.

[3] A. Subiyakto, A. R. Ahlan, M. Kartiwi, and H. T. Sukmana, "Influences of the Input Factors towards Success of An Information System Project," TELKOMNIKA (Telecommunication Computing Electronics and Control), vol. 13, pp. 686-693, June, 20152015.

[4] A. Subiyakto, A. R. Ahlan, M. Kartiwi, and H. T. Sukmana, "Measurement of Information System Project Success Based on Perceptions of the Internal Stakeholders," International Journal of Electrical and Computer Engineering (IJECE), vol. 5, pp. 271-279, April, 20152015. 
[5] A. Subiyakto, D. Septiandani, E. Nurmiati, Y. Durachman, M. Kartiwi, and A. R. Ahlan, "Managers Perceptions towards the Success of E-Performance Reporting System," TELKOMNIKA (Telecommunication Computing Electronics and Control), vol. 15, pp. 1389-1396, 2017.

[6] R. Nasriyah, Z. Arham, \& Q. Aini, "Profile Matching and Competency Based Human Resources Management Approaches for Employee Placement Decision Support System (Case Study)," Asian Journal of Applied Sciences, vol. 9(2), pp. 75-86, 2016.

[7] C.-T. Chen, W.-Z. Hung, H.-L. Cheng, "Applying Linguistic Promethee Method in Investment Portofolio Decision Making," International Journal of Electronic Bussiness Management, vol. 9, no. 2, pp. 139-148, 2011.

[8] H. Agni F., "Decision Support System Determining Employee Bonuses with Promethee Method," Thesis, UPN Veteran Yogyakarta, Indonesia, 2011. [Indonesian]

[9] S. C. Indriatoro, "Decision Support System of Web based Supersemar Scholarship using Promethee Method," Jurnal Manajemen Informatika, vol. 5, no. 1, pp. 10-17, 2016. [Indonesian]

[10] Z. Taha and S. Rostam, "A hybrid fuzzy AHP-Promethee decision support system for machine tool selection in flexible manufacturing cell," Journal of Intelligent Manufacturing, vol. 23, no. 6, pp. 21372149, 2012.

[11] D. Metin, "Decision Making in Equipment Selection: An Integrated Approach with AHP and Promethee," Journal of Intelligent Manufacturing, vol. 19, pp. 397-406, 2008.
[12] E. Turban, J. E. Aronson, and T. L. Peng, Decision Support System and Intelligent System. New Jersey: Pearson Education, 2005.

[13] K. Sri, H. Sri, H. Agus, and W. Retanto, Fuzzy Multi-Attribute Decision Making (Fuzzy MADM). Yogyakarta: Graha Ilmu, 2006. [Indonesian]

[14] J. P. Brans and PH. Vincke, "A preference ranking organisation method," Management Science, vol. 31, no. 6, pp. 647-656, 1985.

[15] Structural Discourse of Idealization and Implementation of Decision-Making Concepts. Bandung: PT. Remaja Rosdakarya, 2002. [Indonesian]

[16] Sholiq. Pemodelan Sistem Informasi Berorientasi Objek Dengan UML. Yogyakarta: Graha Ilmu, 2006. [Indonesian]

[17] B. Sidik, Pemrograman Web dengan PHP. Bandung: Informatika, 2006. [Indonesian]

[18] R. Soetam, Konsep Dasar Rekayasa Perangkat Lunak (Software Engineering). Jakarta: Prestasi Pustaka Publisher, 2011. [Indonesian]

[19] N. Hakiem, A. Mutholib, and U. Aditiawarman, "Mobile based development of a voter information management system (sipendalih) for the 2014 Indonesian presidential election: Case of Indonesian voters in Malaysia," in Information and Communication Technology for The Muslim World (ICT4M), 2014 The 5th International Conference on, 2014, pp. 1-4.

[20] Q. Aini and B. La Katjong, "Application development of mobile Transjakarta route map:(case study: Jakarta Indonesia)," in Proceedings of the 9th International Conference on Advances in Mobile Computing and Multimedia, 2011, pp. 264-267. 